\title{
PEMACUAN PERTUMBUHAN IKAN NILA (Oreochromis niloticus)MELALUI PENERAPAN SISTEM BIOFILTER DAN AERASI DI KOLAM TADAH HUJAN
}

\author{
Bambang Gunadi"), Lies Setijaningsih"), Chairulwan Umar ${ }^{*}$
}

\begin{abstract}
ABSTRAK
Kualitas air kolam tadah hujan yang cepat memburuk mengakibatkan penurunan laju pertumbuhan ikan yang dipelihara. Untuk mengatasi hal tersebut, penelitian pemacuan pertumbuhan ikan nila di kolam tadah hujan telah dilaksanakan di Balai Penelitian Perikanan Air Tawar, Sukamandi. Ikan nila hitam(Oreochromis niloticus) berukuran 42,8 g/ekor ditebar di sembilan kolam tadah hujan berukuran $3 \times 6 \mathrm{~m}^{2}$ dengan kepadatan $10 \mathrm{ekor} / \mathrm{m}^{2}$. Tiga buah kolam dilengkapi dengan teknik biofilter, tiga buah dengan aerasi dan tiga buah lainnya merupakan kontrol. Pakan buatan berbentuk pelet tenggelam diberikan sebanyak $3 \%$ bobot biomassa ikan/hari. Percobaan dilakukan dengan rancangan acak lengkap dalam tiga ulangan.

Hasil pengamatan selama 12 minggu menunjukkan bahwa penerapan sistem biofilter dan aerasi di kolam tadah hujan dapat meningkatkan laju pertumbuhan, sintasan dan menurunkan konversi pakan ikan nila hitam $(\mathrm{P}<0,1)$. Pertambahan bobot biomassa total ikan nila selama 12 minggu pada perlakuan biofilter, aerasi dan kontrol masing-masing adalah $11.326,13( \pm 2.017,80)$ g, 13.573,73 $( \pm 727,95)$ g dan 5.838,15 ( $\pm 2771,08) \mathrm{g}$, sedangkan laju harian pertumbuhan individunya adalah $1,14( \pm 0,14) \%, 1,29( \pm 0,07) \%$ dan $0,95( \pm 0,03) \%$, masing-masing untuk perlakuan biofilter, aerasi dan kontrol. Tingkat sintasan untuk perlakuan biofilter, aerasi dan kontrol masing-masing adalah $94,44( \pm 1,47) \%, 93,33( \pm 3,38) \%$ dan $79,44( \pm 18,86) \%$, sedangkan konversi pakannya adalah $2,96( \pm 0,58), 2,41( \pm 0,13)$ dan $6,31( \pm 2,99)$ masing-masing untuk perlakuan biofilter, aerasi dan kontrol.
\end{abstract}

ABSTRACT: The enhancement of the growth of nile tilapia (Oreochromis niloticus) by the application of biofilter and aeration systems in rainfed ponds. By: Bambang Gunadi, Lies Setijaningsih and Chairulwan Umar.

The poor quality of water in the rainfed-pond resulted in low growth rate of cultured fish. To overcome this problem, experiment on the enhancement of tilapia growth in the rainfed-pond was conducted in the Research Instituie for Freshwater Fisheries, Sukamandi. Nile tilapia with initial weight of $42.8 \mathrm{~g} /$ fish were stocked in the rainfed pond of $3 \times 3 \mathrm{~m}^{2}$ at the density of $10 \mathrm{fish} / \mathrm{m}^{2}$. Three ponds were equipped with biofilters, three other ponds used aeration system and the last three ponds were used as controls. Commercial pelleted feed were given at a feeding rate of $3 \%$ total biomass/day. The experiment was designed in the Completely Randomized Design with three replication.

The results of the 12-week experiment showed that water quality improvement techniques applied in the rainfed ponds were able to increase the growth rate, survival rate and feed conversion $(F C R)$ of the nile tilapia $(P<0,1)$. The increment of the total fish biomass in ponds equipped with biofilter, aeration and control were $11,326.13( \pm 2,017.80) \mathrm{g}, 13,573.73( \pm 727.95) \mathrm{g}$ and 5,838.15 $( \pm 2,771.08) \mathrm{g}$, respectively. The individual daily growth rate of fish in these treatments were 1.14 $( \pm 0.14) \%, 1.29( \pm 0.07) \%$ and $0.95( \pm 0.03) \%$ respectively, the survival rate of tilapias for the biofilter, aeration and control treatments were $94.44( \pm 1.47) \%, 93.33( \pm 3.38) \%$ and $79.44( \pm 18.86) \%$, respectively. The feed conversion rate (FCR) of fish in these treatments were $2.96( \pm 0.58), 2.41$ $( \pm 0.13)$ and $6.31( \pm 2.99)$, respectively.

Keywords: Growth, biofilter, aeration, rainfed-pond.

\footnotetext{
*) Peneliti pada Balai Penelitian Perikanan Air Tawar
} 


\section{PENDAHULUAN}

Salah satu kendala dalam pengembangan teknologi kolam tadah hujan adalah mutu air yang cepat menurun bahkan bisa mencapai di bawah ambang batas kelayakan bagi ikan. Hal ini disebabkan karena pasokan air ke kolam tadah hujan hanya mengandalkan curah hujan, sehingga pergantian air di dalam kolam sangat sedikit dan bahkan sering tidak ada sama sekali. Menurut Gunadi et al. (1996), pada penelitian kolam tadah hujan di Sukamandi terjadi penurunan kandungan oksigen terlarut dalam air sampai $0,3 \mathrm{mg} / \mathrm{L}$, amonia meningkat sampai 1,25 $\mathrm{mg} / \mathrm{L}$ dan populasi plankton melimpah (plankton blooming).

Sementara itu Sutrisno et al. (1992), menyatakan bahwa di kolam tadah hujan terjadi fluktuasi harian mutu air yang cukup tinggi. Pada siang hari, kandungan oksigen terlarut dapat mencapai $14 \mathrm{mg} / \mathrm{L}$ sedangkan pada pagi hari turun hingga mencapai $0,2 \mathrm{mg} / \mathrm{L}$. Konsentrasi karbondioksida bebas pada pagi hari meningkat hingga mencapai $33 \mathrm{mg} / \mathrm{L}$, sedangkan pada siang hari mencapai titik terendah yaitu $5 \mathrm{mg} / \mathrm{L}$. Bagi sebagian besar ikan air tawar, kondisi seperti tersebut sudah tidak layak untuk pertumbuhan bahkan dapat mengakibatkan kematian.

Agar kondisi air kolam senantiasa layak untuk budidaya ikan maka perlu diterapkan teknik penyegaran air sebagai upaya perbaikan mutu air kolam. Beberapa teknik dapat dilaksanakan antara lain penyaringan (filtrasi), aerasi dan penambahan bahan penyegar. Dalam teknik filtrasi berlangsung dua proses penyaringan yakni fisik dan biologis. Clarkson \& Lane (1991), menyatakan bahwa biofilter (filter biologis) dapat diterapkan untuk mengatasi masalah kandungan amonia yang tinggi yang disebabkan oleh sisa metabolisme ikan, di mana amonia diubah menjadi nitrit dan kemudian dioksidasi menjadi nitrat. Secara umum Wheaton (1977), menyatakan bahwa dalam sistem filtrasi biologis terjadi pengubahan senyawaan $\mathrm{N}$-organik menjadi nitrat secara bakteriologis. Proses utamanya adalah konversi amonia menjadi nitrit dan selanjutnya nitrit menjadi nitrat. Dalam filter biologis umumnya terdapat lapisan padat yang berongga (berpori-pori) di mana bakteri nitrifikasi hidup.

Peningkatan produksi dan tingkat konsumsi ikan terhadap pakan dapat mengakibatkan salah satu fungsi trofik dari suatu ekositem yaitu dekomposisi menjadi tidak mampu menjalankan tugasnya karena terlalu berlebihan. Hal ini akan memperburuk kondisi lingkungan melalui peningkatan jumlah sisa metabolisme, berkurang. nya oksigen terlarut dan sebagainya. Untuk mengatasi hal tersebut diperlukan stimulasi buatan bagi proses dekomposisi (mineralisasi) guna memulihkan kembali penyimpangan fungsi tropik tersebut, yaitu dengan cara penambahan aerasi (Zonneveld et al., 1991). Selain aerasi, terdapat beberapa metode untuk memperbaiki mutu air kolam budidaya ikan, seperti: sirkulasi, pengeringan dan pembuangan endapan dasar kolam, oksidasi endapan dasar, pencucian kolam dengan arus deras atau dengan perbaikan desain kolam agar pembuangan sisa lebih sempurna (Rogers, 1989). Parker \& Suttle (1987), menyatakan bahwa sirkulasi dan aerasi terhadap air kolam dapat meningkatkan produktivitas primer, mengurangi stratifikasi, meningkatkan kelarutan nutrien, mengurangi akumulasi bahan organik di dasar kolam dan meningkatkan produksi kolam.

Tujuan dari kegiatan penelitian ini adalah untuk mendapatkan informasi tentang efektivitas sistem biofilter dan aerasi terhadap laju pertumbuhan dan produksi ikan nila yang dipelihara di kolam tadah hujan. Melalui penerapan sistem biofilter dan aerasi kualitas air di kolam tadah hujan akan dapat dipertahankan atau bahkan lebih layak bagi kehidupan ikan nila sehingga dapat menghasilkan laju pertumbuhan dan produksi maksimal ikan nila di kolam tadah hujan.

\section{BAHAN DAN METODE}

Penelitian ini dilaksanakan di Balai Penelitian Perikanan Air Tawar Sukamandi pada musim hujan selama 12 minggu. Penelitian dilaksanakan dengan menggunakan rancangan percobaan acak lengkap dalam tiga kali ulangan. Perlakuan terdiri atas (1) penerapan teknik biofilter, (2) penerapan teknik aerasi dan (3) kontrol (tanpa biofilter dan tanpa aerasi). Pada perlakuan biofilter dipergunakan bak filter berukuran $0,5 \mathrm{~m}^{3}$ dengan lapisan filter berturut-turut dari dasar adalah ijuk, pasir dan koral. Volume lapisan filter sekitar $0,15 \mathrm{~m}^{3}$. Air dipompa dari kolam dialirkan ke dasar bak filter mengalir ke atas dan akhirnya kembali ke kolam. Debit air yang melewati bak filter rata-rata $0,75 \mathrm{~L} /$ detik. 
Pada perlakuan aerasi, udara dialirkan dari satu blower ke dalam tiga buah kolam secara merata melalui pipa dan selang aerasi yang pada ujungnya terdapat batu aerasi. Dalam setiap kolam terdapat empat buah titik aerasi dengan debit udara masing-masing titik rata-rata 0,15 $\mathrm{L} /$ detik.

Kolam percobaan berupa kolam tadah hujan berukuran $3 \times 6 \mathrm{~m}^{2}$, berdinding tembok dengan dasar tanah, sebanyak 9 buah. Kedalaman air dipertahankan setinggi $90 \mathrm{~cm}$. Pasokan air berasal dari air hujan. Penambahan air dari saluran irigasi dilakukan hanya untuk mengganti kehilangan karena penguapan dan perembesan.

Pengukuran dan pengamatan parameter mutu air, kecuali suhu air, dilakukan setiap dua minggu pada waktu pagi (pukul 05.30) dan sore hari (pukul 17.30). Oksigen terlarut diukur dengan DO-meter YSI 51B, $\mathrm{pH}$ air diukur dengan $\mathrm{pH}$-meter Orion 230A, karbondioksida bebas $\left(\mathrm{CO}_{2}\right)$ diukur dengan metode fenolphthalin sedangkan amonia $\left(\mathrm{NH}_{4}{ }^{+} \mathrm{N}\right)$ diukur secara spektrofotometrik dengan metode Nessler. Suhu air diukur setiap hari dengan termometer air raksa minimum-maksimum.

Jenis ikan yang dipelihara adalah ikan nila hitam (O.niloticus), yang berasal dari Balai Benih Ikan (BBI) Dinas Perikanan Kabupaten Dati II Bogor. Sebelum ditebar ikan diadaptasikan terlebih dulu di kolam penampungan di Sukamandi. Ikan ditebar dengan bobot awal rata-rata 42,80 g/ekor dengan kepadatan $10 \mathrm{ekor} / \mathrm{m}^{2}$.

Pakan yang diberikan berupa pakan buatan berbentuk pellet tenggelam dengan kadar protein $28 \%$. Jumlah pemberian pakan per hari adalah $3 \%$ dari bobot ikan yang diberikan tiga kali. Pemberian pakan dilakukan dengan mempergunakan wadah berupa tambir yang digantung sekitar 50 $\mathrm{cm}$ di bawah permukaan air pada setiap kolam. Dengan adanya wadah ini dapat diketahui nafsu makan ikan. Jika terdapat sisa pakan, pemberian pakan berikutnya dikurangi dan sisa ransum pada hari itu ditambahkan kepada ransum hari berikutnya. Penyesuaian bobot pakan dilakukan setiap dua minggu sesuai dengan selang waktu pengamatan bobot ikan.

Pengambilan sampel ikan dan pengukuran kualitas air dilakukan setiap dua minggu. Ikan sampel sebanyak 50 ekor/kolam ditangkap dengan jaring tarik dan serok, ditimbang dengan cara penimbangan basah. Ikan yang mati dihitung dan ditimbang setiap hari. Bobot rata-rata individu dikalikan dengan sisa jumlah ikan merupakan bobot biomassa total ikan di dalam kolam. Penimbangan ikan mempergunakan timbangan O-HAUSS kapasitas $25 \mathrm{~kg}$.

Data hasil pengukuran bobot ikan sampel digunakan untuk menghitung pertumbuhan individu, produksi dan efisiensi pakan. Data dianalisis secara statistik dengan program statistik Ver 3.0 (NH Analytical Software). Analisis data mempergunakan metode uji sidik ragam (Analysis of Variance-ANOVA) dilanjutkan dengan uji Beda Nyata Terkecil (Least Significant Difference- $L S D$ ) pada $\mathrm{P}=0,05$ dan $\mathrm{P}=0,1$.

\section{HASIL DAN PEMBAHASAN}

\section{Kualitas Air}

Nilai rata-rata beberapa parameter kualitas air selama percobaan tercantum pada Tabel 1. Kadar oksigen terlarut pada pagi hari antara perlakuan biofilter dan aerasi tidak menunjukkan perbedaan $(\mathrm{P}>0,1)$ yakni masing-masing $2,92( \pm$ $0,59) \mathrm{mg} / \mathrm{L}$ dan $2,57( \pm 0,13) \mathrm{mg} / \mathrm{L}$. Sementara itu pada perlakuan kontrol kadar oksigennya lebih kecil dibandingkan dengan kedua perlakuan tersebut yakni $1,51( \pm 0,08) \mathrm{mg} / \mathrm{L}$. Pada sore hari, kadar oksigen terlarut pada perlakuan aerasi yakni $6,25( \pm 0,34) \mathrm{mg} / \mathrm{L}$ lebih tinggi dibandingkan dengan perlakuan biofilter yakni 4,60 ( $1,05) \mathrm{mg} / \mathrm{L}$, sedangkan kadar yang paling tinggi terjadi pada perlakuan kontrol yakni $7,46( \pm 0,55)$ $\mathrm{mg} / \mathrm{L}$. Dengan demikian pada perlakuan kontrol terjadi fluktuasi paling besar di mana pada pagi hari kadar oksigen terlarutnya mencapai 1,5 ( $0,08) \mathrm{mg} / \mathrm{L}$, paling rendah dibandingkan dua perlakuan lainnya, sedangkan pada sore harinya mencapai 7,46 $( \pm 0,55) \mathrm{mg} / \mathrm{L}$ adalah paling tinggi dibandingkan dengan perlakuan biofilter dan aerasi: Kadar oksigen pada perlakuan kontrol sangat dipengaruhi oleh aktivitas fotosintesis dan respirasi biota di dalam kolam, sekaligus juga menggambarkan populasi plankton dan biota lain yang tinggi. Fluktuasi kadar oksigen terlarut yang tinggi di kolam tadah hujan juga ditemukan pada penelitian terdahulu yang dilakukan olah Sutrisno et al. (1992). Penerapan tehnik biofilter dan aerasi dapat mencegah terjadinya fluktuasi harian kadar oksigen terlarut yakni antara pagi dan sore hari. 
Tabel 1. Nilai rata-rata dua mingguan parameter kualitas air di kolam tadah hujan selama 12 minggu. Table 1. Biweekly average values of water quality parameters in the rainfed pond for 12 weeks.

\begin{tabular}{|c|c|c|c|}
\hline \multirow{2}{*}{$\begin{array}{l}\text { Parameter/ } \\
\text { Parameters }\end{array}$} & \multicolumn{3}{|c|}{ Perlakuan (Treatments) } \\
\hline & Biofilter & Aerasi (Aeration) & Kontrol (Control) \\
\hline $\begin{array}{l}\text { Oksigen terlarut (Dissolved } \\
\text { oxygen) } \\
\text { - pagi (morning) } 05.30 \mathrm{am} \\
\text { - sore (afternoon) } 05.30 \mathrm{pm}\end{array}$ & $\begin{array}{l}2.92( \pm 0.59)^{\mathrm{a}} \\
4.60( \pm 1.32)^{\mathrm{a}}\end{array}$ & $\begin{array}{l}2.57( \pm 0.13)^{\mathrm{a}} \\
6.25( \pm 0.34)^{\mathrm{b}}\end{array}$ & $\begin{array}{l}1.51( \pm 0.08)^{b} \\
7.46( \pm 0.55)^{c}\end{array}$ \\
\hline $\begin{array}{l}\text { Karbondioksida bebas } \\
\text { Carbondioxyde } \\
\text { - pagi (morning) } 05.30 \mathrm{am} \\
\text { - sore (afternoon) } 05.30 \mathrm{pm}\end{array}$ & $\begin{array}{l}7.15( \pm 0.43)^{\mathrm{a}} \\
6.70( \pm 1.32)^{\mathrm{a}}\end{array}$ & $\begin{array}{l}7.29( \pm 1.09)^{\mathrm{a}} \\
6.66( \pm 0.43)^{\mathrm{a}}\end{array}$ & $\begin{array}{l}7.80( \pm 0.20)^{\mathrm{a}} \\
6.15( \pm 0.78)^{\mathrm{a}}\end{array}$ \\
\hline $\begin{array}{l}\text { Keasaman }(\mathrm{pH}) \\
\text { - pagi }(\text { morning) } 05.30 \mathrm{am} \\
\text { - sore (afternoon) } 05.30 \mathrm{pm}\end{array}$ & $\begin{array}{l}7.48( \pm 0.02)^{\mathrm{a}} \\
7.40( \pm 0.10)^{\mathrm{a}}\end{array}$ & $\begin{array}{l}7.49( \pm 0.06)^{\mathrm{a}} \\
7.57( \pm 0.11)^{\mathrm{ab}}\end{array}$ & $\begin{array}{l}7.46( \pm 0.08)^{\mathrm{a}} \\
7.60( \pm 0.11)^{\mathrm{b}}\end{array}$ \\
\hline $\begin{array}{l}\text { Amonia (Ammonia) }(\mathrm{mg} / \mathrm{L} \mathrm{NH} 4+-\mathrm{N}) \\
\text { - pagi (morning) } 05.30 \mathrm{am} \\
\text { - sore (afternoon) } 05.30 \mathrm{pm}\end{array}$ & $\begin{array}{l}0.234( \pm 0.069)^{\mathrm{a}} \\
0.215( \pm 0.040)^{\mathrm{a}}\end{array}$ & $\begin{array}{c}0.174( \pm 0.019)^{\mathrm{ab}} \\
0.124( \pm 0.017)^{\mathrm{b}}\end{array}$ & $\begin{array}{l}0.151( \pm 0.009)^{b} \\
0.111( \pm 0.036)^{b}\end{array}$ \\
\hline $\begin{array}{l}\text { Nitrit (Nitrite) } \quad(\mathrm{mg} / \mathrm{L} \mathrm{NO} 2) \\
\text { - pagi (morning) } 05.30 \mathrm{am} \\
\text { - sore (afternoon) } 05.30 \mathrm{pm}\end{array}$ & $\begin{array}{l}0.423( \pm 0.081)^{\mathrm{a}} \\
0.384( \pm 0.371)^{\mathrm{a}}\end{array}$ & $\begin{array}{l}0.315( \pm 0.009)^{b} \\
0.342( \pm 0.015)^{b}\end{array}$ & $\begin{array}{l}0.272( \pm 0.033)^{b} \\
0.261( \pm 0.006)^{c}\end{array}$ \\
\hline $\begin{array}{l}\text { Suhu air (Water temperature }) \\
\text { - minimum (minimum }) \\
\text { - maksimum (maximum })\end{array}$ & $\begin{array}{c}26-33 \\
29-33.5\end{array}$ & $\begin{array}{c}26-33 \\
29-33.5\end{array}$ & $\begin{array}{c}26-33 \\
29-33.5\end{array}$ \\
\hline
\end{tabular}

\footnotetext{
Angka dalam kurung menunjukkan simpangan baku (Values in the parenthesis indicate standard deviation)

- Angka rata-rata dalam baris dengan notasi huruf yang berbeda menunjukkan perbedaan yang nyata (Mean values in rows with different notation indicate statistically significant difference) $(\mathrm{P}<0.1)$.
}

Timbulnya fluktuasi harian kadar oksigen terlarut tersebut terutama berkaitan dengan kelimpahan fitoplankton di dalam kolam yang secara visual dapat terlihat dari warna air. Jika plankton makin melimpah, warna air kolam semakin berwarna hijau dan pekat. Pada perlakuan kontrol, plankton lebih melimpah dibandingkan dengan perlakuan lain. Hal ini menyebabkan proses fotosintesis pada siang hari yang menghasilkan oksigen terlarut pada perlakuan kontrol terjadi lebih besar dibandingkan dengan perlakuan biofilter dan aerasi, sehingga pada sore hari kadar oksigen terlarutnya lebih besar. Pada perlakuan biofilter, pasokan oksigen terlarut pada siang hari dari hasil proses fotosintesis paling kecil dibandingkan dengan perlakuan lainnya. Hal ini disebabkan oleh populasi fitoplankton yang rendah sebagai akibat terserap dan akhirnya tertahan di dalam filter. Kondisi ini ikut menunjang lebih cepatnya pemampatan biofilter, selain disebabkan oleh tingginya kandungan bahan organik dan koloid atau lumpur yang terlarut di dalam air (Tabel 2).

Pada saat kritis yakni pada pagi hari, pemberian aerasi sebesar $0,15 \mathrm{~L} /$ detik sebanyak empat titik di dalam kolam seluas $18 \mathrm{~m}^{2}$ mampu mempertahankan kadar oksigen terlarut lebih tinggi $70,2 \%$ dibandingkan dengan kontrol. Teknik serupa (namun tidak dijelaskan berapa debit udara yang dihasilkan) yang diterapkan 
untuk keramba jaring apung selama 12 jam pada malam hari dan mampu meningkatkan kadar oksigen sebesar $51,70 \%$ pada pagi hari (Hadie et al., 1996. Pada perlakuan biofilter, meskipun tidak mendapatkan aerasi, kadar oksigen terlarut pada pagi hari relatif tidak berbeda $(P>0,1)$ dengan perlakuan aerasi. Hal ini diduga berkaitan dengan rendahnya populasi plankton sehingga penurunan kadar oksigen terlarut selama malam hari akibat terpakai dalam proses respirasi oleh plankton tidak sebanyak pada perlakuan lain.

Kadar karbondioksida bebas untuk semua perlakuan baik pada pagi hari maupun sore hari tidak terdapat adanya perbedaan $(\mathrm{P}>0,1)$. Hal yang hampir serupa juga terjadi untuk $\mathrm{pH}$ air, meskipun pada sore hari $\mathrm{pH}$ air pada perlakuan biofilter cenderung lebih rendah dibandingkan dengan perlakuan yang lainnya. Kadar $\mathrm{CO}_{2}$ dan $\mathrm{pH}$ sangat dipengaruhi oleh proses fotosintesis dan respirasi jasad nabati yang terdapat di dalam air (Zonneveld et al., 1991). Penurunan $\mathrm{pH}$ air atau peningkatan keasaman air pada perlakuan biofilter juga berkaitan dengan aktivitas nitrifikasi yang lebih tampak pada perlakuan tersebut di mana kadar $\mathrm{NO}_{2}$ lebih tinggi $(\mathrm{P}<0,1)$ dibandingkan dengan perlakuan lain (Tabel 1). Secara umum dapat dikatakan baik kadar karbondioksida bebas maupun $\mathrm{pH}$ air masih layak untuk mendukung kehidupan dan pertumbuhan ikan nila.

Kadar amonia merupakan hasil akhir metabolisme protein, oleh karenanya dipengaruhi oleh kadar oksigen terlarut, suhu air, kadar protein dalam pakan dan tingkat efisiensi pakan. Pada budidaya ikan secara intensif, pemberian pakan buatan dalam intensitas yang tinggi akan menghasilkan penumpukan amonia secara drastis dalam waktu singkat karena tiadanya pergantian air. Menurut Zonneveld et al. (1991), pemberian pakan kepada ikan dalam bentuk pellet sebanyak $1 \mathrm{~kg}$ dapat menghasilkan $\mathrm{NH}_{4}{ }^{+}-\mathrm{N}$ sebesar $30 \mathrm{~g}$. Dengan penerapan teknik biofilter yang baik, problema seperti ini akan dapat diatasi.

Tujuan utama penerapan teknik biofilter adalah pengubahan amonia menjadi nitrit dan selanjutnya nitrit menjadi nitrat secara bakteriologis (Wheaton, 1977). Pengubahan ini merupakan suatu usaha yang sangat penting mengingat

Tabel 2. Kepadatan plankton rata-rata pada setiap air sampel (sel/L).

Table 2. Mean densities of plankton found in 1 liter water sample (cell/L).

\begin{tabular}{lccc}
\hline \multirow{2}{*}{$\begin{array}{c}\text { Jenis plankton } \\
\text { Plankton species }\end{array}$} & \multicolumn{3}{c}{ Perlakuan (Treatment) } \\
\cline { 2 - 4 } & $\begin{array}{c}\text { Biofilter } \\
\text { Biofilter }\end{array}$ & $\begin{array}{c}\text { Aerasi } \\
\text { Aeration }\end{array}$ & $\begin{array}{c}\text { Kontrol } \\
\text { Control }\end{array}$ \\
\hline Pediastrum & 1.933 & 2.303 & 3.594 \\
Scenedes & 53 & 237 & 386 \\
Oscilatoria & 409 & 1.088 & 1.314 \\
Chlorella & 1.522 & 2.912 & 5.048 \\
Dictyosphaerium & 21 & 84 & 158 \\
Botryococcus & 14 & 32 & 41 \\
Cosmarium & 66 & 531 & 666 \\
Melosira & 3 & 10 & 13 \\
Nauplius & 7 & 26 & 31 \\
Cyclops & 3 & 14 & 17 \\
Lyngbia & 32 & 111 & 238 \\
\hline
\end{tabular}


amonia merupakan senyawa yang sangat beracun bagi ikan, sementara itu nitrit tidak begitu beracun sedangkan nitrat hampir tidak beracun sama sekali bagi kebanyakan organisme akuatik. Pada penelitian ini proses pengubahan tersebut tampak terjadi pada perlakuan biofilter, terbukti dengan kadar $\mathrm{NO}_{2}$ yang lebih tinggi $(\mathrm{P}<0,1)$ dibandingkan dengan perlakuan aerasi maupun kontrol. Proses nitrifikasi dapat berlangsung jika di dalam air atau sedimen terdapat oksigen dan ion amonium (Fry, 1987).

Penerapan teknik aerasi dapat juga mengatasi masalah amonia meskipun secara tidak langsung. Tujuan utama pemberian aerasi adalah untuk meningkatkan kadar oksigen terlarut di dalam air. Melalui aerasi proses difusi oksigen udara ke dalam air berlangsung lebih cepat melalui interaksi antara molekul air dengan gelembung udara yang disemprotkan ke dalam air (Rogers, 1989). Peningkatan kadar oksigen di dalam air akan menurunkan tingkat kelarutan senyawa beracun dalam air sekaligus mengurangi daya racun amonia. Secara keseluruhan kadar amonia dan - nitrit yang terukur dalam penelitian ini masih jauh dari ambang batas yang dapat mempengaruhi kehidupan ikan. Meskipun daya racun senyawa amonia amat bergantung kepada suhu dan $\mathrm{pH}$ air, secara umum kadar amonia sebesar $2,0 \mathrm{mg} / \mathrm{L}$ mengakibatkan keracunan yang akut bagi ikan mas (Kawamoto dalam Zonneveld et al., 1991), sedangkan sampai kadar $400 \mathrm{mg} / \mathrm{L}$ nitrat tidak mempunyai pengaruh buruk ter-hadap pertumbuhan ikan maupun aktivitas makan (Knepp \& Arkin dalam Wheaton, 1977).

\section{Pertumbuhan dan Produksi}

Pertambahan bobot biomassa total ikan nila selama pemeliharaan 12 minggu dengan perlakuan biofilter dan aerasi lebih tinggi $(\mathrm{P}<0,05)$ dibandingkan dengan perlakuan kontrol sedangkan antara perlakuan biofilter dan aerasi tidak menunjukkan adanya perbedaan (Tabel 3). Pertambahan bobot biomassa untuk ketiga perlakuan adalah $11.326,13( \pm 2.017,80) \mathrm{g}, 13.573,73( \pm$ $727,45) \mathrm{g}$ dan $5.838,15( \pm 2.771,08) \mathrm{g}$, masingmasing untuk perlakuan biofilter, aerasi dan kontrol. Sementara itu, pertumbuhan bobot individu ikan nila antar ketiga perlakuan menunjukkan adanya perbedaan $(\mathrm{P}<0,1)$ di mana perlakuan aerasi memberikan pertumbuhan paling tinggi yakni $84,00 \pm 7,90 \mathrm{~g}$, disusul per- lakuan biofilter $(69,28 \pm 13,26 \mathrm{~g})$ dan perlakuan kontrol yakni $52,25( \pm 2,25) \mathrm{g}$. Hal yang sama juga berlaku pada laju pertumbuhan harian individu, di mana perlakuan aerasi memberikan laju pertumbuhan paling tinggi yakni 1,29 ( \pm $0,07) \%$ /hari, disusul perlakuan biofilter $(1,14 \pm$ $0,14 \%$ /hari) dan perlakuan kontrol yang memberikan laju pertumbuhan paling kecil yakni 0,95 ( \pm $0,03) \% /$ hari.

Laju pertumbuhan ikan terutama ditentukan oleh kadar oksigen terlarut (Zonneveld et al., 1991). Pada penelitian ini, laju pertumbuhan ikan nila sejalan dengan kadar oksigen terlarut. Perlakuan aerasi, kadar oksigen terlarutnya relatif paling tinggi dibandingkan dengan perlakuan biofilter dan kontrol. Laju pertumbuhan ikan juga paling tinggi di antara ketiga perlakuan.

Secara umum dapat dikatakan bahwa penerapan teknik penyegaran (biofilter dan aerasi) menunjukkan hasil yang lebih baik dibandingkan dengan tanpa teknik penyegaran (kontrol). Hasil penelitian dengan teknik penyegaran ini lebih baik dibandingkan dengan penelitian pemeliharaan ikan nila sebelumnya. Pada penelitian terdahulu, laju pertumbuhan harian ikan nila yang dipelihara secara campur kelamin tanpa dibuang anak adalah $1,12 \%$ /ekor/hari dan $1,11 \%$ /ekor/hari untuk pemeliharaan campur kelamin dengan pembuangan anakannya (Gunadi et al., 1996).

\section{Sintasan dan Konversi Pakan}

Dari segi sintasan ikan nila hitam di kolam tadah hujan selama 12 minggu, pada umumnya penerapan teknik penyegaran air relatif memberikan efek yang lebih baik dibandingkan dengan tanpa penyegaran (kontrol). Pada Tabel 3 terlihat bahwa tingkat sintasan ikan nila yang dipelihara di kolam tadah hujan selama 12 minggu dengan perlakuan biofilter sebesar 94,44 $( \pm 1,47 \%)$ tidak berbeda dengan sintasan ikan nila pada perlakuan aerasi yakni 93,33 ( $\pm 3,38 \%$ ), tetapi lebih tinggi dibandingkan dengan perlakuan kontrol. Sementara itu tingkat sintasan pada perlakuan aerasi tidak berbeda dengan tingkat sintasan ikan nila pada perlakuan kontrol yakni $79,44( \pm 18,86 \%)(\mathrm{P}>0,1)$. Rendahnya tingkat sintasan ikan pada perlakuan kontrol diduga berkaitan dengan kadar oksigen terlarut yang sangat berfluktuasi di mana pada saat yang kritis kurang mendukung kehidupan ikan. Pada pagi 
Tabel 3. Pertambahan bobot biomassa dan individu, laju pertumbuhan harian individu, sintasan dan konversi pakan ikan nila (O. niloticus) di kolam tadah hujan selama 12 minggu.

Table 3. Total biomass and individual weight increment, individual daily growth rate, production, survival rate and feed conversion ratio of tilapia (O.niloticus) reared in the rainfed pond for 12 weeks.

\begin{tabular}{|c|c|c|c|c|c|}
\hline \multirow{2}{*}{\multicolumn{2}{|c|}{$\begin{array}{l}\text { Parameter/ } \\
\text { Parameters }\end{array}$}} & \multicolumn{3}{|c|}{ Perlakuan (Treatments) } & \\
\hline & & $\begin{array}{l}\text { Biofilter } \\
\text { Biofilter }\end{array}$ & $\begin{array}{c}\text { Aerasi } \\
\text { Aeration } \\
\end{array}$ & $\begin{array}{l}\text { Kontrol } \\
\text { Control }\end{array}$ & \\
\hline $\begin{array}{l}\text { Pertambahan bobot biomassa } \\
\text { Total biomass increment }\end{array}$ & (g) & $\begin{array}{l}11.326 .13^{\mathrm{a}} \\
( \pm 2.017 .80)\end{array}$ & $\begin{array}{l}13.573 .73^{\mathrm{a}} \\
( \pm 727.95)\end{array}$ & $\begin{array}{c}5.838 .15^{\mathrm{b}} \\
( \pm 2.771 .08)\end{array}$ & $\mathrm{P}<0.05$ \\
\hline $\begin{array}{l}\text { Pertambahan bobot individu } \\
\text { Individual weight increment }\end{array}$ & (g) & $\begin{array}{c}69.28^{\mathrm{b}} \\
( \pm 13.26)\end{array}$ & $\begin{array}{l}84.00^{\text {a }} \\
( \pm 7.90)\end{array}$ & $\begin{array}{l}52.25^{\mathrm{c}} \\
( \pm 2.25)\end{array}$ & $\mathrm{P}<0.1$ \\
\hline $\begin{array}{l}\text { Laju pertumbuhan harian indiv } \\
\text { Individual daily growth rate }\end{array}$ & $\begin{array}{l}\text { idu (\%.hari) } \\
\text { (\%/day) }\end{array}$ & $\begin{array}{c}1.14^{b} \\
( \pm 0.14)\end{array}$ & $\begin{array}{c}1.29^{\mathrm{a}} \\
( \pm 0.07)\end{array}$ & $\begin{array}{c}0.95^{\mathrm{c}} \\
( \pm 0.03)\end{array}$ & $\mathrm{P}<0.1$ \\
\hline $\begin{array}{l}\text { Produks } \\
\text { Production }\end{array}$ & $\begin{array}{r}(\mathrm{kg} / \mathrm{kolam}) \\
(\mathrm{kg} / \text { pond })\end{array}$ & $\begin{array}{l}19.03^{b} \\
( \pm 2.02)\end{array}$ & $\begin{array}{l}21.27^{\mathrm{a}} \\
( \pm 0.07)\end{array}$ & $\begin{array}{c}9.79^{\mathrm{c}} \\
( \pm 6.79)\end{array}$ & $\mathrm{P}<0.1$ \\
\hline Laju sintasan (Survival rate) & (\%) & $\begin{array}{l}94.44^{\text {a }} \\
( \pm 1.47)\end{array}$ & $\begin{array}{l}93.33^{\mathrm{ab}} \\
( \pm 3.38)\end{array}$ & $\begin{array}{c}79.44^{\mathrm{b}} \\
( \pm 18.86)\end{array}$ & $\mathrm{P}<0.1$ \\
\hline $\begin{array}{l}\text { Konversi pakan (Feed } \\
\text { conversion ratio) }\end{array}$ & & $\begin{array}{c}2.96^{\mathrm{a}} \\
( \pm 0.58)\end{array}$ & $\begin{array}{c}2.41^{\mathrm{a}} \\
( \pm 0.13)\end{array}$ & $\begin{array}{c}6.31^{\mathrm{b}} \\
( \pm 2.99)\end{array}$ & $\mathrm{P}<0.1$ \\
\hline
\end{tabular}

Angka dalam kurung menunjukkan simpangan baku (Value in the parenthesis indicate standard deviation).

Angka rata-rata dalam baris dengan notasi huruf yang berbeda menunjukkan perbedaan yang nyata (Mean values in rows with different notation indicate statistically significant difference) $(\mathrm{P}<0.1)$.

hari kadar oksigen terlarut pada perlakuan kontrol rata-rata $1,51( \pm 0,08) \mathrm{mg} / \mathrm{L}$ (Tabel 1$)$.

Hal yang hampir sama dengan tingkat sintasan juga berlaku untuk konversi pakan, di mana konversi pakan pada perlakuan biofilter dan aerasi tidak menunjukkan perbedaan, sedangkan antara kedua perlakuan ini dengan perlakuan kontrol menunjukkan perbedaan yang nyata $(\mathrm{P}<0,1)$. Konversi pakan bagi ikan nila yang dipelihara di kolam tadah hujan selama 12 minggu dengan perlakuan biofilter, aerasi dan kontrol masing-masing adalah $2,96( \pm 0,58) ; 2,41$ $( \pm 0,13)$ dan 6,31 ( $\pm 2,99)$.

Nilai konversi pakan ikan nila di kolam tadah hujan menunjukkan bahwa perlakuan biofilter dan aerasi memberikan pengaruh yang lebih baik dibandingkan dengan perlakuan kontrol (Tabel 2). Kenaikan nilai konversi pakan yang berarti menurunnya tingkat efisiensi pakan berkaitan dengan menurunnya mutu air. Mutu air yang tidak layak mengakibatkan nafsu makan ikan berkurang sehingga banyak sisa pakan yang terbuang yang pada akhirnya akan mengakibatkan tingginya nilai konversi pakan.

Secara ringkas dapat dikatakan bahwa penerapan teknik biofilter dan aerasi dapat mempertahankan tingkat sintasan serta menurunkan konversi pakan ikan nila hitam di kolam tadah hujan.

\section{KESIMPULAN}

Penerapan teknik biofilter dan aerasi di kolam tadah hujan dapat meningkatkan laju pertumbuhan dan sintasan serta menurunkan konversi pakan ikan nila yang dipelihara di kolam tadah hujan. 


\section{DAFTAR PUSTAKA}

Balarin, J.D. 1988. Development planning for tilapia in Africa.p.531-538. In R.S.V. Pullin, T. Bhukaswan, K. Tonguthai and J.L. Maclean (cds). The Second International Symposium on Tilapia in Aquaculture. ICLARM Conference Proceeding15. Dept of Fisheries, Bangkok, Thailand and International Centre for Living Aquatic Resources Management, Manila, Philipinnes. 623 p.

Clarkson, R. and S.D. Lane. 1991. Use of a small-scale nutrient-film hydrophonis technique to reduce mineral accumulation in aquarium water. Aquaculture and Fisheries Management, 22:37-45.

Fry, J.C. 1987. Functional roles of major groups of bacteria associated with detritus. In D.J.W. Moriarty and R.S.V. Pullin (eds) Detritus and microbial ecology in aquaculture. ICLARM Conference Proceeding 14, 420 p. International Centre for Living Aquatic Resources Management, Manila, Philippinnes. p.82-122.

Gunadi, B., Z. Jangkaru dan M. Sulhi. 1996. Memacu laju pertumbuhan ikan nila campur kelamin dalam kolam tadah hujan melalui pembuangan jaring apung. Pros. Sem. Ilmiah Hasil Penel. 1994/1995. Balitkanwar, Sukamandi. Hal. 150-158.

Hadie, W., Jaelani, L.E. Hadie dan D.I. Achmadipura. 1996. Pengaruh aerasi terhadap pertumbuhan dan konversi pakan ikan mas di keramba jaring apung. Pros. Sem. Ilmiah Hasil Penel. 1994/1995. Balitkanwar, Sukamandi. Hal. 143-149.

Parker, N.C. and M.A. Suttle. 1987. Design of airlift pumps for water circulation and aeration in aquaculture. Aquaculture Engineering, 6:97-110.

Rogers, G.L. 1989. Aeration and circulation for effective aquaculture pond management. Aquaculture engineering, 8:349-355.

Sutrisno, S. Koesoemadinata dan R.Utami 1992. Penelitian aspek kualitas air terhadap budidaya ikan gurame di kolam tadah hujan. Pros.Sem.Hasil Penel.Perik.Air Tawar 1991/1992. Balai Penelitian Perikanan Air Tawar, Bogor. Hal 131-134.

Wheaton, F.W.1977. Aquaculture engineering. John Wiley \& Sons, New York. 708p.

Zonneveld, N., E.A. Huisman \& J.H. Boon. 1991. Prinsip-prinsip budidaya ikan. Gramedia Pustaka Utama, Jakarta. 336 hal. 